\title{
10. As if for a thousand years - the challenges ahead for the APS ${ }^{1}$
}

\author{
David Borthwick
}

David Borthwick graduated from Monash University with Honours in economics in 1972 and joined the Department of Treasury the following year. The son of Bill Borthwick, a former Liberal Deputy Premier of Victoria and the first Minister for Conservation/the Environment in Australia, David would go on to serve as Secretary to the federal equivalent of the department his father once headed. David left Treasury in 1974 to join the Industries Assistance Commission before returning to his old department in 1979, where he would stay for the next 19 years, aside from a posting as Australian Ambassador to the OECD (1991-93). Between 1993 and 2004 he held a number of deputy secretary positions, first in Treasury, then in the Department of Health and Aged Care, and finally in the Department of the Prime Minister and Cabinet. David Borthwick served as Deputy Secretary of the Department of Health and Aged Care between 1998 and 2001 and Deputy Secretary of the Department of the Prime Minister and Cabinet between 2001 and 2004. He became Secretary of the Department of the Environment, Water, Heritage and the Arts in 2004.

In April 1971, two years before I joined the Australian Public Service, the first meeting of Victoria's Land Conservation Council was held in the old Cabinet Room of Melbourne's Treasury Building. At that meeting, the Minister for Conservation gave a rousing speech and impressed upon the twelve new councillors their historic responsibility to make recommendations on the use of public lands 'as if for a thousand years'. The minister believed that the best conservation outcomes would be achieved if the councillors took a longer-term view. $^{2}$

The minister was my father, the late Bill Borthwick. Today, I pinch myself that I am retiring from the Australian Public Service as Secretary of the Department for the Environment, Water, Heritage and the Arts when my father, as a member of the Victorian government, entered the ministry as Minister for Water Supply and went on to serve as Victoria's first Minister for Conservation. He founded the Victorian Environment Protection Authority and oversaw a vast expansion of the state's national parks system.

\footnotetext{
1 This speech was delivered in March 2009 at a function hosted by the Australian Public Service Commission.

2 Clode, D As if for a thousand years: a History of Victoria's Land Conservation and Environment Conservation Councils, Melbourne: Victorian Environmental Assessment Council, 2006.
} 
I mention my father not because I intend to give you a blow-by-blow account of my family history or my career in the Australian Public Service, but because I think his was sage advice when he implored the Land Conservation Council to make decisions 'as if for a thousand years'. He firmly believed in taking a longer-term, national interest perspective.

For our nation to thrive in a rapidly changing and often confronting world, we need to be far-sighted in developing public policy, whether it be economic, environmental, social or foreign policy. The Australian Public Service has a critical role in helping governments to take such a longer-term view.

I would like to use this occasion to address some of the issues that I think are important for public policy and for Australia's national interest for the future. But firstly, and to provide some context for these thoughts, I would like to reflect on some of the forces shaping Australia and the Australian Public Service over my 36 years as a public servant.

\section{Looking back}

The Australian Public Service I joined in 1973 as a Treasury graduate was markedly different than that of today. Indeed, the nation was very different. In 1973, the Rolling Stones, Suzi Quatro, the Carpenters and Roberta Flack were topping the singles charts and people were tuning their televisions in to Number 96.

The number of people in Australia was less than 14 million and the population was much more concentrated in the south-eastern states ${ }^{3}$ than it is today. Australians did not travel very frequently; the distance the average Australian travelled by air was more than four-fold lower than it is today. ${ }^{4}$ Although telecommunications was a significant industry by the 1970s, many rural Australians were still without adequate phone lines. And it would be more than two decades before internet addresses became available to the general public ${ }^{5}$ (and more than three decades before I fully figured out how to use mine). Australians were physically and technologically much less connected.

\footnotetext{
3 Source: Australian Bureau of Statistics (2008) Australian Historical Population Statistics (cat. no. 3105.0.65.001), viewed 30 November 2008.

4 A comparison of domestic air travel in Australia between 1972/3 and 2003/4. Average distance travelled in 1972/73 was calculated by dividing the total distance (kilometres) of passenger travel by air in 1972/73 by the Australian population in 1973. Average distance travelled in 2003/04 was calculated by dividing the total distance (kilometres) of passenger travel by air in 2003/04 by the Australian population in 2004. Source of air travel data: Bureau of Infrastructure, Transport and Regional Economics, 2008, Australian Transport Statistics Year Book 2007, BITRE, Canberra ACT. Source of population data: Australian Bureau of Statistics (2008) Australian Historical Population Statistics (cat. no. 3105.0.65.001), viewed 30 November 2008. 5 Source: Australian Bureau of Statistics (2001) A History of Communications in Australia (Feature Article) in Year Book Australia 2001.
} 
The foundations of the Australian economy were also very different. Manufacturing was a much bigger component of the national economy, as was agriculture. ${ }^{6}$ Since the 1970s, we have witnessed a boom in the services industry, particularly in the property, business, finance and insurance industries, and an increase in the relative contribution of mining to GDP.

In the early 1970s, the Australian economy was wrapped in the cotton wool of tariffs, industry subsidies, tax concessions and ill-directed regulation. The effective rate of industry assistance for manufacturing was more than fivefold what it is today, and approximately double for agriculture. ${ }^{8}$ To say that we had properly functioning labour and capital markets would be delusional. Government administration comprised more than five per cent of GDP, the highest contribution since federation, with the notable exceptions of the depression and possibly World War II. ${ }^{9}$

The Australian economy was a closed book. While we may have thought of ourselves as a substantial trading nation, we were not. The total value of goods and services imports, expressed as a percentage of GDP, was less than a third of today's value, and the total export value was just over half what it is today. ${ }^{10}$ Thus Australians were not just less connected with each other; they were less connected with the world.

As a result of Australia's inward-looking approach, its rigid product and labour markets and undeveloped financial markets, the economy was in bad shape. Australia's GDP per capita, which had historically been well above the OECD average, was sliding towards a below-average report card.

6 Source: Australian Bureau of Statistics (2005) 100 years of change in Australian industry (Feature Article) in Year Book Australia 2005.

7 Source: Australian Bureau of Statistics (2005) 100 years of change in Australian industry (Feature Article) in Year Book Australia 2005.

8 Source: Productivity Commission

9 Contribution of the 'government administration and defence' industry to GDP was over 5\% during the period 1972/3 to 1983/4. Between 1989/90 and 2000/0 it stayed in the narrow band of $4.1-4.5 \%$. Government contribution peaked at $5.8 \%$ in $1930 / 01$ around the start of the Depression (data is not available for World War II years, but it is expected that the contribution was higher still). Source: Australian Bureau of Statistics (2005) 100 years of change in Australian industry (Feature Article) in Year Book Australia 2005. The definition of 'government administration and defence' is based on the Australia and New Zealand Standard Industrial Classification (ANZSIC), 1993 version, and broadly equates to departmental spending for the general government sector.

10 Total value of goods and services imports was calculated by expressing 'Chain Volume Measures: Goods and Services Debits' as a percentage of GDP for financial years ending June 1973 and 2008. Total value of goods and services exports was calculated by expressing 'Chain Volume Measures: Goods and Services Credits' as a percentage of GDP for financial years ending June 1973 and 2008. Source of CVM: Goods and Services Credits/ Debits data: Australian Bureau of Statistics (2008) Balance of Payments and International Investment Position, Australia (cat. no. 5302.0), viewed on 30 November 2008. Source of GDP data: Australian Bureau of Statistics (2008) Australian Economic Indicators (cat. no. 1350.0), viewed on 30 November 2008. 
With the benefit of hindsight

The Australian Public Service I joined in 1973 was in the throes of a debate between free trade and protectionism, or, as I saw it, a debate between economic common sense and the 'dark side'. This national battle of philosophies - of how to run the place - was reflected within the Australian Public Service. There was considerable ill will between departments, particularly Treasury, Trade and Industry officials, and personal, often heated, exchanges between departmental secretaries.

The Australian Public Service I joined - indeed Australia - was at a crossroads. Collegiality was minimal. Departmental officials believed that what was in their sector's interest was in the national interest. They fought hard to boost sectoral interests. Treasury was not immune either; although it was good at pointing out the failings of other departments, it too was guilty of overzealous regulation in its own patch.

But on this battleground, some powerful ideas emerged. Alf Rattigan was Chairman of the Tariff Board when I joined the service. He had been appointed back in the mid 1960s by the then Deputy Prime Minister, Sir John McEwen, because of his perceived protectionist leanings.

Sadly for Sir John, his appointed gamekeeper turned out to be a poacher. While Rattigan was initially cautious, he soon became a champion for economic reform. This period was a defining moment for Australia. The removal of the protectionist straitjacket in all its guises was led by Rattigan. Australia began to focus on issues of economic or resource efficiency, on stimulating productivity and lifting the nation's long-term growth potential.

Rattigan had a profound influence on the nation: he laid the foundations for Australia's future prosperity. He also had a profound influence on my career. I moved from the Treasury to the newly formed Industries Assistance Commission (the successor of the Tariff Board) in 1974. That period of the mid-1970s had a major impact on my approach to working in the Australian Public Service.

Rattigan shaped my views on the importance of pursuing the long-term national interest, rather than sectoral interests, and the importance of examining economy-wide implications of public policy choices. He impressed upon me the value of robust analysis, openness and public inquiry. Most importantly, he made me realise that public servants could exert a major influence on the course of the nation's fortunes. And so, all fired up from my early years in Treasury and the Industries Assistance Commission, I embarked eagerly on a public service career that has lasted 36 years.

What are the biggest changes I have witnessed over those 36 years? Firstly, I think the Australian Public Service has matured greatly. Today there is a much stronger focus on developing public policy that is genuinely in the national 
interest and, consequently, there is a much stronger focus on working together. Departments cooperate significantly more than they used to, and there is a greater sense of collegiality among the upper echelons of the service.

It is just as well that the Australian Public Service has matured - or perhaps it is not surprising - given that the issues governments are grappling with today are significantly more complex than they were in 1973. This is the second major change I have witnessed: an increase in the complexity of government business. Government business is more complex because Australia is more entrenched in the global economy and more exposed to the world in general. (The trade figures I referred to earlier are prime evidence of this, as are the massive financial flows in and out of Australia). In this world, governments must be on the front foot because competitive pressures are intense. And they must be ready to respond to global events, because, as we are currently reminded, the nation's fortunes can be buffeted by the rises and falls in other major economies.

Let me digress here and say a few words about the current international economic crisis. Economists are not very good at picking turning points, or the magnitude of events. They are, however, better at pointing out underlying pressures; at identifying the fundamentals. The growing major financial (and real) imbalances between the United States and China, to mention the most prominent example, have been apparent since the late 1990s. It was the main topic of debate in financial market meetings I attended during the latter part of the 1990s. These imbalances are truly massive: China's current account surplus peaked at around eleven per cent of GDP in 2007; the United States' current account deficit peaked at around 6.5 per cent of GDP. The vast flow of funds into the United States (that is the counterpart of their current account deficit) is reflective of persistent macro and micro economic policy failures in both countries.

The United States was not so much putting capital inflows into investments which could service the debt over time as into current public and private consumption, including housing. In essence, the capital inflows fuelled the boom that subsequently precipitated the collapse as the United States Federal Reserve belatedly sought to dampen domestic demand by tightening monetary policy.

The world is now wearing the consequences of speculative bubbles originating in the United States property market, inadequate financial market regulatory frameworks, and the collective loss of confidence affecting asset values, precipitating further contagion effects. Understandably, investors and consumers are confused. A return to more normal conditions is a long way off. 
With the benefit of hindsight

Inevitably, Australia has been swept up in such events; we cannot avoid the consequences of poor policy in other countries. But we can be prepared for them. Although we are being severely buffeted, we are in much better shape than most other countries because during the 1990s we reinforced the independence of the Reserve Bank, adopted longer-term monetary policy (aimed at keeping inflation in the two to three per cent range) and fiscal rules of thumb (achieving balance over the course of the economic cycle).

Of particular importance is the fact that in the 1990s we fundamentally changed the way we prudentially regulate the financial sector, forming the Australian Prudential Regulatory Authority covering essentially the entire sector. In this regard, Australia was well ahead of many other nations. Australia's prescience - or sound public policy - championed by the Treasury has stood us in good stead.

However, our situation stands in stark contrast to the financial regulatory shambles now exposed in so-called 'international financial centres'. One need only consider the ad-hoc and ill-conceived financial regulatory structure in the United States; look at the way administrations have run fiscal settings, particularly over the last ten years. Consequently, the United States now finds itself confronted with a disastrous budget deficit of around 12 per cent of GDP.

In short, good public policy - getting the underlying framework right - really does matter and in that regard, while we will undoubtedly have lessons to learn ourselves, we have been on the front foot and the Australian Public Service has been at the forefront of formulating good policy. Beyond the immediate economic issues, governments must be able to adapt quickly, because new ideas and technologies are developed and transmitted so readily. And they must be prepared and able to work with other nations because many problems economic, social, and environmental - are truly global in nature.

Let me be clear. I am strongly of the view that Australia's greater engagement with the world, through trade and financial flows and our advances in communications, and the increased mobility of people and ideas, is a very good thing. However, as I have underscored by example of Australia's far-sighted fiscal and monetary policy management and financial market regulation, it does have consequences for the way Australia positions itself for those challenges. Let me elaborate further. 


\section{Challenges for government}

\section{Pursuing longer-term reforms}

I started my address by emphasising the need to take a longer-term national rather than a sectoral perspective: 'as if for a thousand years'. One major challenge for government is pursuing a reform agenda in the face of extreme pressure from vocal single interest groups. Often the costs are upfront and obvious whereas the benefits, although much greater, are diffuse and longterm. Specific interest groups that stand to lose have become increasingly savvy at harnessing the power and reach of the media and the susceptibility of our politicians to push their particular cause. And, more than ever, governments are reactive to the intense pressure of the 24-hour news cycle. Sadly, responding to the shrill voices of sectoral interests too often gets in the way of long-term policy development in the national interest.

It is confronting this reality that I have found to be the most challenging and sometimes frustrating aspect of being a public policy adviser. The biggest tension between politicians and their public servant advisers resolves around this issue. The irony is, while we are much more enlightened now than we were in the 1970s regarding the importance of pursuing the national interest, it is always, unfortunately, a close-run thing.

Some might say: 'is there harm in making a few concessions here and there to sectoral interests?' But the fact remains that the accumulation of bad decisions or indecision will catch up with nations and is ultimately reflected in their standard of living. Of course, governments have to strike a balance. But exactly where that balance is struck needs to reflect the outcome of a fully informed assessment of where the national interest truly lies.

How can governments better ensure that the pursuit of longer-term reforms is not hijacked by the opportunistic demands of special pleaders? First, we need to undertake rigorous analysis of different policy choices drawing on economic, scientific and social considerations. Wherever possible, that should include cost: benefit analysis. Of course, not everything can be accurately weighed in dollar terms, but in all instances there needs to be a careful weighing of pros and cons so that quantitative and qualitative judgements can be made. We also need to remain realistic about what we can and cannot do: a nation cannot afford to fund every policy initiative which has a favourable cost: benefit ratio.

Secondly, we need to open up the debate over long-term policy choices. We need to better equip the public to understand the complexity of issues and the productive and contrary qualities of different options. Rattigan was a great 
With the benefit of hindsight

believer in having transparent public policy processes. There needs to be more public releases of research papers, discussion papers and inquiries addressing policy issues of national importance. In this regard, some have criticised the plethora of reviews and inquiries currently being undertaken by the Commonwealth. While the proof of these reviews will be in the outcomes, this is a development that I welcome. It is certainly more effective than inaction or half-baked decisions that are taken on the run, often pandering to the squeakiest wheel.

Thirdly, the proper working of the cabinet system of government is imperative. I am concerned that we have slowly edged towards a de facto presidential style of government, without sufficient checks and balances. As an illustration, during my time in the Australian Public Service some of the most important decisions were made by the Prime Minister, sometimes with a small group of senior ministers. Cabinet was little more than a formality; a rubber stamp. Indeed, the Australian system is, in some respects, becoming more presidential in character but without the checks and balances that are on the President of the United States.

Governments usually start with good intentions but fall into bad habits. Ideas need to be debated and tested in a properly informed cabinet forum. I am not arguing that every idea needs to go to cabinet (in fact I think too many inconsequential items reach the Cabinet agenda), but it is critical that cabinet properly considers the issues of national importance.

\section{Commonwealth-state relations}

Another major challenge for the national government, which is a product of Australia's higher exposure to the world and the increased mobility of people and ideas, is a change in Commonwealth-state relations. Over time, our views on what issues should be handled at the national level have broadened and increasingly more responsibility has been acquired by the Commonwealth. The Commonwealth has gathered greater control via legislative means (High Court decisions, assertion of existing constitutional powers and occasionally, referral of state powers) and perhaps most significantly, via financial instruments such as specific purpose payments.

I believe this trend is unlikely to be reversed and the Commonwealth government will acquire more responsibility over time. Now this will not always be the Commonwealth's choosing, as Canberra will continue to be drawn into issues of state responsibility by the community, who view the Commonwealth as a de facto 'court of appeal'. Is this trend towards more centralised government a 
bad thing? Some would argue that it represents a departure from subsidiarity principle: that is, the Commonwealth is taking on responsibility for programs and services it is not best placed to deliver.

I do not believe this is the case, because these days physical proximity does not necessarily make a government better equipped to administer a program. The Commonwealth government is absolutely capable of developing strategies for managing complex projects at a local level, and delivering services across Australia which cater to the different needs of different communities.

Nevertheless, the acquisition of new responsibilities does bring with it new challenges. It puts the onus on the Commonwealth government and the Australian Public Service to do more of the longer-term, strategic analysis across a broader range of issues. This includes clarifying the boundaries in key areas of split Commonwealth-state responsibility such as health, education and transport to ensure the effective delivery of services.

The centralisation we are seeing on a national scale is also happening at an international scale. As I discussed previously, Australia is more entrenched in the global economy and will, increasingly, be shaped by global forces and events. We are most likely to thrive if we have a strong economy and a healthy society. This only reinforces the need for the Commonwealth government to be far-sighted in its approach to issues.

\section{Issues for the Australian Public Service}

I will now turn my attention to issues for the Australian Public Service. The Australian Public Service clearly has a critical role in helping governments to rise to challenges I have described. What then are the ingredients for a healthy Australian Public Service that can assist governments to pursue longer-term reforms across an increasingly broader range of responsibilities?

\section{The first ingredient: finding the space for longer-term thinking}

The quality of the Australian Public Service is the foundation of good government. It must have the capacity - the skilled workforce and the resources - to undertake the strategic thinking which underpins longer-term reforms. Institutions such as the Productivity Commission, which have a long-term orientation and some degree of independence from government, are vitally important. But they are not enough. The capacity for longer-term thinking needs to exist across the service, in each agency with policy responsibilities. 
With the benefit of hindsight

I think it is becoming increasingly difficult for the Australian Public Service to find room to do this. It has sometimes been said that the Australian Public Service is strong on policy but weaker on program implementation. Certainly officers with policy skills have tended to move up the ranks more rapidly. My concern is that the Australian Public Service is being tasked to do so much that the balance is tipping the other way. The immediate pressures of program and service delivery take priority over long-term policy development.

This is one of the great difficulties of being an agency head: we want to provide a longer-term perspective to government but our agencies are so flat out and stretched that we have scant capacity to invest in serious thinking. My concern is that the less we engage in thinking about longer-term policy issues, the less capable we become of engaging in it when it is required. I would hate to see the Australian Public Service become de-skilled to the point that it cannot participate in a meaningful way in setting out the nation's long-term agenda. Rattigan would have been dismayed.

\section{The second ingredient: being business-like}

I think the Australian Public Service needs to be more business-like in the way it develops, implements and evaluates policies and programs. All too often, we find ourselves landed with the daunting task of implementing a new initiative which has only been developed to the extent required to prepare the one page new policy proposal for the Expenditure Review Committee of cabinet.

Instead, we need to spend more time researching and assessing different policy options before picking a course of action. On this point, I refer back to my previous comments about the need for rigorous analysis to weigh up the merits of different policy choices; of taking the longer-term national perspective.

The Australian Public Service also needs to put more effort into rigorously reviewing and evaluating the success of different policies and programs, something we do not do nearly enough. We need to know which initiatives have not worked, or have not worked perfectly. That way, when governments need to make savings, they can target programs with a less favourable cost: benefit ratio. I do not think governments are serious enough about evaluating programs and closing them down when required; all too often, necessary savings are achieved by shaving funds at the margins across the board.

This presents a great dilemma for secretaries. Secretaries are responsible under the Financial Management and Accountability Act 1997 for the financial oversight of their department. Yet under our system they do not really have the freedom to run their own shop. Ministers continually ask departments to do more but are rarely willing to cut things off. It is little wonder that departments are 
struggling to find the resources to invest in longer term strategy development: it is debilitating. One way around this may be to 'activity cost' everything we do, just like the leading edge of the private sector. In this world, if ministers want their departments to undertake a new activity then they should have to identify, at the same time, what they are not going to do. As things currently stand, the gradual accretion of new functions that have not been funded is debilitating to the capacity to focus on longer-term issues, yet it is an accepted part of today's APS.

\section{The third ingredient: accountability}

The Australian Public Service is by far Australia's biggest business and is arguably more complex than the businesses run by our private sector counterparts. But unlike our private sector counterparts, the Australian Public Service is not subject to market disciplines; it is a monopoly provider of services. The public has little choice but to deal with us. Consequently, it is incumbent on the Australian Public Service to apply high ethical and administrative standards, and to be accountable in general.

It is critical that we maintain 'accountability' institutions such as the Australian National Audit Office, the Ombudsman, the Administrative Appeals Tribunal and our accountability to parliament. Uncomfortable though it may be at times, we need to allow ourselves to be questioned and probed about the quality of service we are delivering on behalf of the Australian people, remembering that it is politicians who are ultimately accountable.

We need to be as open as possible about the way we do things, and we need to actively promote a pro-information disclosure environment (to the extent that it does not compromise the free exchange of ideas between the public service and ministers). Releasing more information into the public domain helps build trust in government and government processes and, most importantly, it encourages a more open debate on longer-term policy issues.

\section{Concluding remarks}

The Australian Public Service is a great asset to this nation and I have every confidence that it will rise to the challenges I have described. The quality of the service it provides and the standard of conduct is world class. So too is the capability and commitment of its people. Earlier, I spoke of the profound influence that one public servant, Alf Rattigan, had on turning around 
the fortunes of the nation. He is a fine example, but he is only one of many Australian Public Service 'heroes' who have made a difference, and who I have been privileged to witness at work over the past 36 years.

The Australian Public Service and the nation have fundamentally changed over the past 40 years; so too will they fundamentally change over the next 40 . Reforms such as the Carbon Pollution Reduction Scheme, which today seem momentous, may well be viewed as minor adjustments 40 years hence. In 40 years time, we may reflect with nostalgia on the time when public servants congregated for work in the parliamentary triangle; where my generation saw the advent of the personal computer, the next generation may well witness the demise of the 'office and desk' and the creation of a more fluid, flexible and dispersed workforce.

I cannot predict how the Australian Public Service will change, short of predicting that the Commonwealth government will be doing more, but experience tells me it will change. I shall leave it to a future secretary to reflect on these changes in his or her valedictory address, 40 years from now.

Being in the Australian Public Service has been a rewarding experience. Many of my public sector values were instilled by my father and role models like Rattigan. While I will undoubtedly miss working in the Australian Public Service and the camaraderie that it has, the last couple of months away from it have confirmed that now was the right time to leave. 